\title{
Characterization of coagulase-positive staphylococci isolated from tank and silo ewe milk
}

\author{
B. Linage, J. M. Rodríguez-Calleja, A. Otero, M. L. García-López, and J. A. Santos ${ }^{1}$ \\ Department of Food Hygiene and Food Technology, Veterinary Faculty, University of León, E-24071 Spain
}

\section{ABSTRACT}

The prevalence of coagulase-positive staphylococci (CPS) was studied among 390 samples of ewe milk. Fifty-seven (14.85\%) samples of tank milk and all samples (6) of silo milk gave a positive result on Baird-Parker agar base supplemented with rabbit plasma fibrinogen, whereas amplification of the coagulase (coa) gene was successful in $6(1.56 \%)$ samples of tank milk and in all silo samples. Phenotypic and genetic analysis of 153 isolates identified 151 (98.69\%) as Staphylococcus aureus. Amplification of the coa gene was positive for 149 isolates (97.39\%). The staphylococcal enterotoxin (SE) $\mathrm{C}$ gene was detected in 116 strains $(75.82 \%)$, whereas more than one SE gene was carried in 5 strains (3.26\%). None of the isolates harbored the genes for SEE or for methicillin resistance. A high prevalence of CPS carrying enterotoxin genes should be of concern because ewe milk is mainly processed into raw milk cheeses. The detection of the coa gene from milk samples could help to assess the microbiological safety of raw milk intended for direct use in the dairy industry.

Key words: coagulase-positive staphylococci, Staphylococcus aureus, sheep milk, coa gene

\section{INTRODUCTION}

Staphylococcus aureus is a human pathogen that is also associated with several animal species, causing infections of major economic importance such as intramammary infections in lactating ruminants. In humans, Staph. aureus can cause toxin-mediated diseases, such as toxic shock syndrome and staphylococcal food poisoning, in addition to skin lesions and systemic infections. Staphylococcal food poisoning is a disease acquired from the consumption of foods contaminated with preformed staphylococcal enterotoxins $(\mathbf{S E})$. The disease is characterized by abdominal cramps, nausea, vomiting, and diarrhea, and it is considered a leading cause of foodborne illness worldwide, although the

Received July 15, 2011.

Accepted November 30, 2011.

${ }^{1}$ Corresponding author: j.santos@unileon.es majority of the cases are not reported (Balaban and Rasooly, 2000; Le Loir et al., 2003; Seo and Bohach, 2007). The SE are heat-stable proteins that are produced by several species of staphylococci, mainly Staph. aureus and other strains of coagulase-positive species, as Staph. intermedius and Staph. hyicus (Le Loir et al., 2003; SCVPH, 2003). Five classical enterotoxins (SEA to SEE) have been described, but modern genomic analysis has allowed the recognition of new SE or SElike toxins (Seo and Bohach, 2007).

Not all the strains present in foods are enterotoxigenic, and the coagulase and thermonuclease tests are very efficient for the identification of potentially enterotoxigenic staphylococci (ICMSF, 1996; Lancette and Bennet, 2001; Le Loir et al., 2003). To cause foodborne intoxication, staphylococci must grow in food to reach a high cell density $\left(\sim 10^{6} \mathrm{cfu} / \mathrm{g}\right.$; Le Loir et al., 2003).

Staphylococcus aureus and other coagulase-positive staphylococci (CPS) are frequent contaminants of milk and dairy products, the most probable source being the udder of the milk animal, but also cross-contamination along the food chain (SCVPH, 2003; ICMSF, 2005). The presence of high numbers of CPS in milk is of concern because it could lead to the production of SE. Current regulations in the European Union (EU) require the use of low temperatures after raw milk collection to avoid growth of CPS, whereas checking their numbers in several dairy products is a process hygiene criterion (European Parliament and Council, 2004; European Commission, 2005). Available surveillance data indicate that in Spain, Staph. aureus was the causative agent of $22(1.8 \%)$ outbreaks of foodborne disease reported in 2003, cheeses being involved in $7(31.8 \%)$ of them (Cevallos et al., 2005). An additional concern arises from the presence of methicillin-resistant Staph. aureus (MRSA) strains in food and food-producing animals, which can be seen as a potential source of community-acquired MRSA, and MRSA are not routinely investigated in foods (EFSA, 2009).

Ewe breeding is an important activity in Spain $(22 \%$ of the EU breeding ewe flock), and it is concentrated particularly in the interior regions, which generate more than $75 \%$ of the Spanish production of ewe milk. The majority of the milk is transformed into cheese and, 
therefore, the knowledge of the prevalence of potential enterotoxigenic strains of staphylococci is of great interest for both milk producers and cheese processors, who will obtain additional proof on the safety of the food commodities.

The aims of this study were (1) to isolate and characterize CPS from samples of tank and silo ewe milk using phenotypic and genotypic methods, and (2) to search for the presence of the genes responsible for the production of classical SE and resistance to methicillin.

\section{MATERIALS AND METHODS}

\section{Milk Samples}

Over a 1-yr period (April 2009 to March 2010), 384 samples were collected from refrigerated tanks of different flocks located in northwest Spain, representing more than 25,000 animals ( $\sim 10 \%$ of Spanish dairy ovine livestock). The milk from the different tank milk collection routes was carried to a milk plant and mixed in silos of up to $60,000 \mathrm{~L}$ capacity, where an additional 6 samples (1 sample per silo) were taken. Fifty milliliters per sample was aseptically collected and returned to the laboratory at $4^{\circ} \mathrm{C}$ in a temperature-controlled cool box.

\section{Microbiological Determinations and Antibiotic Residue Detection}

Total aerobic plate count was determined on plate count agar (Oxoid, Basingstoke, UK) after serial 10fold dilutions of the samples in $0.1 \%$ (wt/vol) peptone (Oxoid) solution. The inoculated plates were incubated at $30^{\circ} \mathrm{C}$ for $72 \mathrm{~h}$.

Enumeration of CPS was done by spreading $0.1 \mathrm{~mL}$ of the milk sample on Baird-Parker agar base supplemented with rabbit plasma fibrinogen (BP-RPF; Biokar Diagnostics, Beauvais, France), following by incubation at $37^{\circ} \mathrm{C}$ for $48 \mathrm{~h}$. Typical black colonies with an opaque halo were picked from plates and stored for further characterization. Also, $0.1 \mathrm{~mL}$ of every milk sample was spread on $5 \%$ sheep blood Columbia agar (Oxoid) and incubated at $37^{\circ} \mathrm{C}$ for $24 \mathrm{~h}$. Colonies showing $\beta$-hemolysis were selected for further studies. A minimum of one suspect colony was picked from the plates; morphological differences (halo size) among typical colonies allowed for selection of more than one isolate from some plates.

The presence of antimicrobial residues was tested using the Blue Yellow II microbial inhibition assay (Charm Sciences Inc., Lawrence, MA; Linage et al., 2007).
Statistical analysis of the results was done with the SPSS software (version 19, IBM Corp., Somers, NY).

\section{Phenotypic Characterization of Isolates}

Presumptive colonies were subjected to the following tests: Gram staining, catalase activity, maltose fermentation, $\beta$-galactosidase activity, clumping factor (Staphaurex, Remel, Lenexa, KS), and coagulase, thermonuclease, and hemolytic activities (García et al., 1980). The gram-positive cocci were further studied with the use of ID 32 Staph galleries (bioMérieux SA, Marcy l'Etoile, France).

\section{PCR Assays in Milk Samples}

Direct detection of the coa gene was attempted from milk samples following the procedure of Goto et al. (2007) that involves centrifugation to recover the bacteria and washing with PBS (Oxoid) plus $0.05 \%$ Tween 20 to remove proteins and lipids. The pellet was digested with $50 \mathrm{U}$ of achromopeptidase (Sigma-Aldrich, St. Louis, MO) to release the DNA. Five microliters of the extracted DNA was used as a template for amplification of a fragment of the coagulase (coa) gene with the primers described by Hookey et al. (1998) and the conditions indicated in Table 1. Milk spiking experiments were previously conducted to rule out the chance of amplification of DNA from dead cells. The results of the PCR were observed after electrophoresis in agarose gel and ethidium bromide staining.

\section{PCR Assays and Molecular Identification of CPS Isolates}

Template DNA was extracted from isolates cultivated in brain-heart infusion broth (Oxoid) for $18 \mathrm{~h}$ at $37^{\circ} \mathrm{C}$. Samples of $1 \mathrm{~mL}$ were centrifuged at $13,000 \times g$ for 5 min at room temperature and the pellet was treated with achromopeptidase as described above. Table 1 shows the primers and the annealing temperatures used for amplification of 16S rDNA (Relman, 1993), the coa gene (Hookey et al., 1998), genes for staphylococcal enterotoxins A through E (sea, seb, sec, sed, and see; Rosec and Gigaud, 2002), and the methicillin resistance (mecA) gene (Smyth et al., 2001). The 16S rDNA amplicons were purified with the Illustra GFX PCR DNA purification kit (GE Healthcare Europe, Barcelona, Spain), analyzed by agarose gel electrophoresis, and partially sequenced in a MegaBACE 1000 sequencer (GE Healthcare Europe). The sequences obtained (approximately $600 \mathrm{bp}$ of the $5^{\prime}$ end) were compared with those available in the Ribosomal Database Project 
Table 1. Targets, PCR primers, annealing temperatures, and expected length of amplicons for genetic screening of coagulase-positive staphylococci

\begin{tabular}{|c|c|c|c|}
\hline $\begin{array}{l}\text { Target } \\
\text { gene }\end{array}$ & $\begin{array}{l}\text { Primer sequence } \\
\left(5^{\prime} \text { to } 3^{\prime}\right)\end{array}$ & $\begin{array}{c}\text { Annealing } \\
\text { temperature }\left({ }^{\circ} \mathrm{C}\right)\end{array}$ & $\begin{array}{l}\text { Expected } \\
\text { amplicon } \\
\text { length (bp) }\end{array}$ \\
\hline $16 \mathrm{~S}$ rDNA & $\begin{array}{l}\text { AGAGTTTGATCCTGGCTCAG } \\
\text { AAGGAGGTGATCCAGCCGCA }\end{array}$ & 55 & 1,500 \\
\hline $\mathrm{coa}$ & $\begin{array}{l}\text { ATAGAGATGCTGGTACAGG } \\
\text { GCTTCCGATTGTTCGATGC }\end{array}$ & 57 & $600-840$ \\
\hline sea & $\begin{array}{l}\text { ACGATCAATTTTTACAGC } \\
\text { TGCATGTTTTCAGAGTTAATC }\end{array}$ & 57 & 544 \\
\hline$s e b$ & $\begin{array}{l}\text { GAATGATATTAATTCGCATC } \\
\text { TCTTTGTCGTAAGATAAACTTC }\end{array}$ & 57 & 416 \\
\hline$s e c$ & $\begin{array}{l}\text { GACATAAAAGCTAGGAATTT } \\
\text { AAATCGGATTAACATTATCCA }\end{array}$ & 57 & 257 \\
\hline sed & $\begin{array}{l}\text { TTACTAGTTTGGTAATATCTCCTT } \\
\text { CCACCATAACAATTAATGC }\end{array}$ & 57 & 334 \\
\hline see & $\begin{array}{l}\text { ATAGATAAAGTTAAAACAAGCAA } \\
\text { TAACTTACCGTGGACCC }\end{array}$ & 52 & 170 \\
\hline mecA & $\begin{array}{l}\text { GCAATCGCTAAAGAACTAAG } \\
\text { GGGACCAACATAACCTAATA }\end{array}$ & 56 & 240 \\
\hline
\end{tabular}

RDP 10.26 (Cole et al., 2009) by multiple sequence alignment. Additional phylogenetic analysis was done with the MEGA v4 software package (Tamura et al., 2007).

\section{RESULTS}

Aerobic plate counts for tank milk samples were between 2.10 and $6.90 \log \mathrm{cfu} / \mathrm{mL}$ (Table 2), with a mean value of $4.72 \log \mathrm{cfu} / \mathrm{mL}$. Silo milk samples showed higher values, ranging between 4 and $7.25 \log \mathrm{cfu} / \mathrm{mL}$ (mean of $5.36 \log \mathrm{cfu} / \mathrm{mL}$ ). Mean values conformed to the EU criterion for raw milk for species other than cow; that is, $<500,000 \mathrm{cfu} / \mathrm{mL}(5.70 \mathrm{log} \mathrm{cfu} / \mathrm{mL})$ or $1,500,000 \mathrm{cfu} / \mathrm{mL}(6.18 \mathrm{log} \mathrm{cfu} / \mathrm{mL})$ when the milk is intended for heat treatment (European Parliament and Council, 2004). However, individual data showed that $42(10.94 \%)$ samples of tank milk were above the lower limit of $5.70 \log \mathrm{cfu} / \mathrm{mL}$, and $14(3.65 \%)$ samples exceeded the higher limit of $6.18 \log \mathrm{cfu} / \mathrm{mL}$. On the other hand, silo milk showed higher mean results than tank milk, and 1 out of the 6 samples (16.67\%) was above the lower limit of $5.70 \log \mathrm{cfu} / \mathrm{mL}$.

Counts of CPS were lower than the detection level $(1 \log \mathrm{cfu} / \mathrm{mL})$ in 327 out of 384 samples $(85.15 \%)$ of tank milk. The remaining 57 samples $(14.85 \%)$ of tank milk showed counts between 1.00 and $1.70 \log \mathrm{cfu} / \mathrm{mL}$ (Table 3). Silo milk samples were always above $2.00 \mathrm{log}$ $\mathrm{cfu} / \mathrm{mL}$ (Table 3). Amplification of the coa gene was successful in 6 samples of tank milk (1.56\%), with CPS levels of 1.48 to $1.70 \mathrm{cfu} / \mathrm{mL}$, and in all the samples taken from silos (Table 3 ).

One sample $(0.26 \%)$ of tank milk gave a positive result for the presence of antimicrobial residues, later confirmed as positive for $\beta$-lactams by the Dairy Interprofessional Laboratory of Castilla y León region. Aerobic plate count for this sample was $4.04 \mathrm{log} \mathrm{cfu} /$ $\mathrm{mL}$ and the CPS count was below the detection level. The milk was rejected for consumption.

A total of 109 CPS isolates from tank milk and 44 from silo milk were selected for characterization. Of these, $142(92.81 \%)$ were obtained from BP-RPF plates showing typical halos, and $11(7.19 \%)$ were $\beta$-hemolytic colonies picked from blood agar plates. All the isolates were gram-positive, catalase-positive cocci, showing a positive $\beta$-galactosidase reaction when tested with the ONPG (ortho-nitrophenyl- $\beta$-D-galactopyranoside) procedure (Oxoid). All but one isolates were able to ferment maltose. Two isolates gave a negative result for the tube coagulase test, but one of them was positive for

Table 2. Aerobic plate counts (APC) and coagulase-positive staphylococci (CPS) counts (all counts in log cfu/ $\mathrm{mL}$ ) found in tank and silo ewe milk

\begin{tabular}{lccccccc}
\hline & \multicolumn{3}{c}{ Tank } & & \multicolumn{3}{c}{ Silo } \\
\cline { 2 - 3 } Count & $\begin{array}{c}\text { Mean } \\
( \pm \text { SD })\end{array}$ & Minimum & Maximum & & $\begin{array}{c}\text { Mean } \\
( \pm \text { SD })\end{array}$ & Minimum & Maximum \\
\hline APC & $4.72 \pm 0.84^{\mathrm{a}}$ & 2.10 & 6.90 & & $5.26 \pm 0.43^{\mathrm{a}}$ & 4.60 & 5.90 \\
CPS & $1.21 \pm 0.22^{\mathrm{a}}$ & $<1.00$ & 1.70 & & $2.70 \pm 0.53^{\mathrm{b}}$ & 2.00 & 3.50 \\
\hline
\end{tabular}

${ }^{\mathrm{a}, \mathrm{b}}$ Means within a row with different superscripts differ $(P<0.05)$. 
Table 3. Counts (log cfu/mL) of coagulase-positive staphylococci (CPS) in tank and silo ewe milk samples and PCR amplification of coagulase (coa) gene

\begin{tabular}{|c|c|c|c|c|c|}
\hline \multicolumn{3}{|c|}{ Tank } & \multicolumn{3}{|c|}{ Silo } \\
\hline Count & $\begin{array}{l}\text { Samples } \\
\text { (no.) }\end{array}$ & $\begin{array}{l}\text { PCR detection } \\
\text { of coa } \text { gene }^{1}\end{array}$ & Count & $\begin{array}{l}\text { Samples } \\
\text { (no.) }\end{array}$ & $\begin{array}{l}\text { PCR detection } \\
\text { of coa gene }\end{array}$ \\
\hline 1.00 & 27 & 0 & 2.00 & 1 & 1 \\
\hline 1.30 & 16 & 0 & 2.30 & 1 & 1 \\
\hline 1.48 & 9 & 3 & 2.60 & 1 & 1 \\
\hline 1.60 & 4 & 2 & 2.84 & 1 & 1 \\
\hline \multirow[t]{2}{*}{1.70} & 1 & 1 & 3.00 & 1 & 1 \\
\hline & & & 3.49 & 1 & 1 \\
\hline
\end{tabular}

${ }^{1}$ Number of samples showing amplification of coa gene.

the clumping factor assay. Three isolates $(1.96 \%)$ were unable to produce thermonuclease. The identification system ID 32 Staph identified 145 isolates (94.77\%) as Staph. aureus, the remaining 8 isolates $(5.23 \%)$ being assigned, with low confidence, to Staph. hominis (4 isolates, 2.61\%), Staph. epidermidis (1 isolate, 0.65\%), intermediate between Staph. aureus and Staph. hominis (1 isolate, 0.65\%), intermediate between Staph. aureus and Staph. xylosus (1 isolate, 0.65\%), and intermediate between Staph. xylosus and Staph. hominis (1 isolate, $0.65 \%$ ). The phylogenetic analysis based on the $16 \mathrm{~S}$ rDNA for these 8 strains assigned 6 of them to Staph. aureus. The intermediate Staph. aureus/Staph. xylosus isolate was assigned to Staph. simulans, and the intermediate Staph. xylosus/Staph. hominis isolate was assigned to Staph. epidermidis.

Amplification of the coa gene yielded a single fragment of a size between 600 and 840 bp for 149 isolates (97.39\%), whereas 4 strains $(2.61 \%)$ presented multiple bands. The sizes of single fragments were $600 \mathrm{bp} \mathrm{(1}$ isolate; $0.65 \%$ ), $680 \mathrm{bp}$ (38 isolates; $24.83 \%$ ), $760 \mathrm{bp}$ (47 isolates; $30.72 \%$ ), and 840 bp (63 isolates; $41.18 \%$ ). Regarding the amplification of SE genes, 116 strains $(75.82 \%)$ harbored the gene for SEC, including the 2 isolates negative for the coagulase test and the 3 thermonuclease-negative isolates, whereas 3 strains $(1.96 \%)$ carried the genes for SEB and SEC, 1 strain $(0.65 \%)$ carried genes for SEC and SED, and 1 strain (0.65\%) carried 4 genes (for SEA, SEB, SEC, and SED). All isolates that carried more than one SE gene were positive for coagulase and thermonuclease. None of the isolates harbored the genes for SEE or for methicillin resistance.

\section{DISCUSSION}

Total aerobic counts found in this study were in agreement with surveys conducted in Spain and other European countries for tank and silo ewe milk (Muehlherr et al., 2003; Sanjuan et al., 2003; Gonzalo et al., 2006; de Garnica et al., 2011). No significant differences were noticed between counts for tank and silo milk, suggesting that storage was done under proper conditions and for short periods (less than $48 \mathrm{~h}$ ); otherwise, significant increases in total aerobic counts would have been observed (Sanjuan et al., 2003).

Current EU regulations do not consider CPS counts as an indicator of hygienic quality of raw milk, but high counts are reliable markers of poor breeding conditions or subclinical mastitis (Klinger and Rosenthal, 1997; Ariznabarreta et al., 2002). Our data show that the prevalence of CPS in tank milk was lower than the figures reported by researchers in Switzerland (Muehlherr et al., 2003) or Norway (Jørgensen et al., 2005), indicating good practices. However, CPS counts increased significantly during storage up to a mean concentration of $2.70 \mathrm{log} \mathrm{cfu} / \mathrm{mL}$ (Table 2), consistent with data obtained by de Garnica et al. (2011). Routine analysis of ewe milk by PCR for detection of the coa gene (especially when intended for manufacturing raw milk cheeses) can be regarded as a useful alternative to CPS counts, being able to reliably detect levels above $2.00 \log \mathrm{cfu} / \mathrm{mL}$ in a shorter time than CPS plate count (Table 3).

The majority of the isolates belonged to Staph. aureus, which is the most frequent species of CPS found in milk and dairy products (Devriese and Hajek, 1980; Rosengren et al., 2010). Phenotypic tests and identification galleries allowed for accurate identification of Staph. aureus isolates, but failed to identify 8 isolates that were assigned to CNS or presented intermediate identifications. Sequence analysis of $16 \mathrm{~S}$ rDNA resolved the ambiguities for the 6 strains clearly clustered to Staph. aureus and for the coagulase-negative isolate, assigned to Staph. epidermidis. The identification of the remaining isolate as Staph. simulans was controversial, because this strain showed a strong coagulase production. Sequencing of $16 \mathrm{~S}$ rDNA is considered discriminative enough for differentiation between the species of the genus Staphylococcus (Becker et al., 2004).The shortcomings of commercial galleries for identifying 
species other than Staph. aureus have been noted by other authors (Becker et al., 2004; Layer et al., 2006). In addition, the results of some assays can be different depending upon the method used, as has been noted for enzymatic activities (Devriese and Hajek, 1980). In this work, the isolates identified as Staph. aureus were always positive for $\beta$-galactosidase when the test was done in tube, but negative when checked in the ID32 Staph gallery. This finding indicates the need for careful interpretation of the $\beta$-galactosidase test when it is important for the identification of CPS.

The coa gene was detected in all isolates with the primers used, even though one of them was considered coagulase-negative both by the tube coagulase test and by the clumping factor assay. The sizes of the amplicons were consistent with the 81-bp tandem repeat sequences described for the coa gene (Kaida et al., 1987) and are similar to the PCR products obtained by Scherrer et al. (2004) with Staph. aureus strains isolated from sheep and goat milk. Moreover, the majority of sheep milk isolates studied by Scherrer et al. (2004) presented a fragment of $820 \mathrm{bp}$, whereas an amplicon of $840 \mathrm{bp}$ was the most frequent in the isolates investigated in this work. In 11 out of the 31 samples with more than one isolate, isolates with amplicons of different lengths were detected, indicating a degree of diversity among isolates from the same farm. In contrast, of the 44 isolates obtained from silo milk samples, $25(56.82 \%)$ presented the same amplicon type ( $840 \mathrm{bp})$.

Amplification of the sea-see genes revealed that sec was the most prevalent type of enterotoxin gene harbored by our CPS isolates. Several earlier studies (Hajek, 1978; Gutiérrez et al., 1982; Orden et al., 1992) on CPS from sheep (nares, udder, and mastitic milk) and sheep cheese reported that SEC was the predominant SE in strains isolated from this small ruminant and its dairy products and also that Staph. aureus strains obtained from sheep belonged to a special group among animal isolates. More recently, sec has been found in ovine isolates as a single gene (Boerema et al., 2006). Molecular typing of animal and human Staph. aureus isolates support the previous evidence for hostspecificity (Fiztgerald and Penadés, 2008; Alves et al., 2009), and Van Leeuwen et al. (2005) added the suggestion that some strains may have adapted to specific tissues such as intramammary tissue. Several authors have reported that some virulence genes may be more commonly associated with strains infecting a particular host (Fiztgerald and Penadés, 2008).

The percentage of enterotoxigenic strains isolated from milk samples varies considerably among different reports: $45.50 \%$ of isolates from farm animals from different countries (Smyth et al., 2005), 65.18\% of strains obtained from sheep and goat milk in Switzerland
(Scherrer et al., 2004), and between 3.30 and $39.70 \%$ in isolates from cow milk in Brazil (Oliveira et al., 2011). Taking into account these figures, the overall incidence found in this work $(83.33 \%)$ can be considered high compared with the percentage of enterotoxigenic strains isolated from ewes with mastitis (Gutiérrez et al., 1982; Orden et al., 1992).

No isolates carrying the $m e c \mathrm{~A}$ gene were found. The presence of MRSA in food samples is of great concern for public health, but the risk appears to be low, considering the numbers reported (EFSA, 2009). Our data reinforced the conclusion that milk is not a common source for human transmission of MRSA (EFSA, 2009; Virgin et al., 2009; Huber et al., 2010).

In conclusion, even though some of the parameters related to the hygienic quality of tank ewe milk can be considered good, the high prevalence of CPS carrying enterotoxin genes should be of concern, as most of the milk production is processed into raw milk cheeses. Direct detection of the coa gene from milk samples can be used as a rapid method to assess the microbiological safety of raw milk regarding CPS.

\section{ACKNOWLEDGMENTS}

This work was supported by Junta de Castilla y León (Ayuda Grupo de Excelencia GR155). Support from the CONSOLIDER - Ingenio 2010: CARNISENUSA (CSD2007-00016) grant is also recognized. The authors are grateful to the Consorcio de Promoción del Ovino for providing samples.

\section{REFERENCES}

Alves, P. D. D., J. A. McCulloch, S. Even, C. Le Maréchal, A. Thierry, N. Grosset, V. Azevedo, C. A. Rosa, E. Vautor, and Y. Le Loir. 2009. Molecular characterisation of Staphylococcus aureus strains isolated from small and large ruminants reveals a host rather than tissue specificity. Vet. Microbiol. 137:190-195.

Ariznabarreta, A., C. Gonzalo, and F. San Primitivo. 2002. Microbiological quality and somatic cell count of ewe milk with special reference to staphylococci. J. Dairy Sci. 85:1370-1375.

Balaban, N., and A. Rasooly. 2000. Staphylococcal enterotoxins. Int. J. Food Microbiol. 61:1-10.

Becker, K., D. Harmsen, A. Mellmann, C. Meier, P. Schumann, G. Peters, and C. von Eiff. 2004. Development and evaluation of a quality-controlled ribosomal sequence database for $16 \mathrm{~S}$ ribosomal DNA-based identification of Staphylococcus species. J. Clin. Microbiol. 42:4988-4995.

Boerema, J. A., R. Clemens, and G. Brightwell. 2006. Evaluation of molecular methods to determine enterotoxigenic status and molecular genotype of bovine, ovine, human and food isolates of Staphylococcus aureus. Int. J. Food Microbiol. 107:192-201.

Cevallos, C., G. Hernández-Pezzi, A. Torres, P. Ordóñez, S. Villarubia, and M. J. Bleda. 2005. Brotes de enfermedades transmitidas por alimentos. España. 2003 (excluye brotes hídricos). Bol. Epidemiol. Semanal. 13:25-31.

Cole, J. R., Q. Wang, E. Cardenas, J. Fish, B. Chai, R. J. Farris, A. S. Kulam-Syed-Mohideen, D. M. McGarrell, T. Marsh, G. M. Garrity, and J. M. Tiedje. 2009. The ribosomal database project: 
Improved alignments and new tools for rRNA analysis. Nucleic Acids Res. 37(Suppl. 1):D141-D145.

de Garnica, M. L., J. A. Santos, and C. Gonzalo. 2011. Influence of storage and preservation on microbiological quality of silo ovine milk. J. Dairy Sci. 94:1922-1927.

Devriese, L. A., and V. Hajek. 1980. Identification of pathogenic staphylococci isolated from animals and foods derived from animals. J. Appl. Bacteriol. 49:1-11.

EFSA. 2009. Scientific opinion of the panel on biological hazards on a request from the European Commission on assessment of the public health significance of meticillin resistant Staphylococcus aureus (MRSA) in animals and foods. EFSA J. 993:1-73.

European Commission. 2005. Commission regulation (EC) no 2073/2005 of 15 November 2005 on microbiological criteria for foodstuffs. Off. J. L338:1-26.

European Parliament and Council. 2004. Regulation (EC) no 853/2004 of the European parliament and of the council of 29 April 2004 laying down specific hygiene rules for on the hygiene of foodstuffs. Off. J. L139:55-205.

Fiztgerald, J. R., and J. R. Penadés. 2008. Staphylococci of animals. Pages 255-269 in Staphylococcus: Molecular Genetics. J. A. Lindsay ed. Caister Academic Press, Norfolk, UK.

García, M. L., B. Moreno, and M. S. Bergdoll. 1980. Characterization of staphylococci isolated from mastitic cows in Spain. Appl. Environ. Microbiol. 39:548-553.

Gonzalo, C., J. A. Carriedo, E. Beneitez, M. T. Juárez, D. L. Fuente, and F. San Primitivo. 2006. Bulk tank total bacterial count in dairy sheep: Factors of variation and relationship with somatic cell count. J. Dairy Sci. 89:549-552.

Goto, M., H. Takahashi, Y. Segawa, H. Hayashidani, K. Takatori, and Y. Hara-Kudo. 2007. Real-time PCR method for quantification of Staphylococcus aureus in milk. J. Food Prot. 70:90-96.

Gutiérrez, L. M., I. Menes, M. L. García, B. Moreno, and M. S. Bergdoll. 1982. Characterization and enterotoxigenicity of staphylococci isolated from ovine mastitic milk in Spain. J. Food Prot. 45:1282-1286

Hajek, V. 1978. Identification of enterotoxigenic staphylococci from sheep and sheep cheese. Appl. Environ. Microbiol. 35:264-268.

Hookey, J. V., J. F. Richardson, and B. D. Cookson. 1998. Molecular typing of Staphylococcus aureus based on PCR restriction fragment length polymorphism and DNA sequence analysis of the coagulase gene. J. Clin. Microbiol. 36:1083-1089.

Huber, H., S. Koller, N. Giezendanner, R. Stephan, and C. Zweifel. 2010. Prevalence and characteristics of meticillin-resistant Staphylococcus aureus in humans in contact with farm animals, in livestock, and in food of animal origin, Switzerland, 2009. Euro Surveill. 15(16):19542.

ICMSF. 1996. Microorganisms in Foods 5: Characteristics of Microbial Pathogens. Blackie Academic \& Professional, London, UK.

ICMSF. 2005. Microorganisms in Foods. 6. Microbial Ecology of Food Commodities. 2nd ed. Kluwer Academic, New York, NY.

Jørgensen, H. J., T. Mørk, H. R. Høgåsen, and L. M. Rørvik. 2005. Enterotoxigenic Staphylococcus aureus in bulk milk in Norway. J. Appl. Microbiol. 99:158-166.

Kaida, S., T. Miyata, Y. Yoshizawa, S. Kawabata, T. Morita, H. Igarashi, and S. Iwanaga. 1987. Nucleotide sequence of the staphylocoagulase gene: Its unique $\mathrm{COOH}$-terminal 8 tandem repeats. J. Biochem. 102:1177-1186.

Klinger, I., and I. Rosenthal. 1997. Public health and the safety of milk and milk products from sheep and goats. Rev. Sci. Tech. 16:482-488.

Lancette, G. A., and R. W. Bennet. 2001. Staphylococcus aureus and staphylococcal enterotoxins. Pages 387-403 in Compendium of Methods for the Microbiological Examination of Foods. 2nd ed. F, P. Downes and K. Ito, ed. APHA, Washington, DC.

Layer, F., B. Ghebremedhin, K. A. Moder, W. Konig, and B. Konig. 2006. Comparative study using various methods for identification of Staphylococcus species in clinical specimens. J. Clin. Microbiol. 44:2824-2830.

Le Loir, Y., F. Baron, and M. Gautier. 2003. Staphylococcus aureus and food poisoning. Genet. Mol. Res. 2:63-76.

Linage, B., C. Gonzalo, J. A. Carriedo, J. A. Asensio, M. A. Blanco, D. L. Fuente, and F. San Primitivo. 2007. Performance of blueyellow screening test for antimicrobial detection in ovine milk. J. Dairy Sci. 90:5374-5379.

Muehlherr, J. E., C. Zweifel, S. Corti, J. E. Blanco, and R. Stephan. 2003. Microbiological quality of raw goat's and ewe's bulk-tank milk in Switzerland. J. Dairy Sci. 86:3849-3856.

Oliveira, A. M., C. R. Padovani, N. T. N. Miya, A. S. Sant'Ana, and J. L. Pereira. 2011. High incidence of enterotoxin D producing Staphylococcus spp. in Brazilian cow's raw milk and its relation with coagulase and thermonuclease enzymes. Foodborne Pathog. Dis. 8:159-163.

Orden, J. A., J. Goyache, J. Hernández, A. Domenech, G. Suárez, and E. Gómez Lucia. 1992. Detection of enterotoxins and TSST 1 secreted by Staphylococcus aureus isolated from ruminant mastitis. Comparison of ELISA and immunoblot. J. Appl. Bacteriol. $72: 486-489$

Relman, D. A. 1993. Universal bacterial 16S rDNA amplification and sequencing. Pages 489-495 in Diagnostic Molecular Microbiology: Principles and Applications. D. H. Persing, T. F. Smith, F. C. Tenover and T. J. White, ed. ASM Press, Washington, DC.

Rosec, J. P., and O. Gigaud. 2002. Staphylococcal enterotoxin genes of classical and new types detected by PCR in France. Int. J. Food Microbiol. 77:61-70.

Rosengren, Å., A. Fabricius, B. Guss, S. Sylvén, and R. Lindqvist. 2010. Occurrence of foodborne pathogens and characterization of Staphylococcus aureus in cheese produced on farm-dairies. Int. J. Food Microbiol. 144:263-269.

Sanjuan, S., J. Rúa, and M. R. García-Armesto. 2003. Microbial flora of technological interest in raw ovine milk during $6^{\circ} \mathrm{C}$ storage. Int J. Dairy Technol. 56:143-148.

Scherrer, D., S. Corti, J. E. Muehlherr, C. Zweifel, and R. Stephan. 2004. Phenotypic and genotypic characteristics of Staphylococcus aureus isolates from raw bulk-tank milk samples of goats and sheep. Vet. Microbiol. 101:101-107.

SCVPH (Scientific Committee on Veterinary Measures Relating to Public Health). 2003. Opinion of the SCVPH on staphylococcal enterotoxins in milk products, particularly cheeses. Accessed June 2011. http://ec.europa.eu/food/fs/sc/scv/out61_en.pdf.

Seo, K. S., and G. A. Bohach. 2007. Staphylococcus aureus. Pages 493-518 in Food Microbiology: Fundamentals and Frontiers. M. P. Doyle and L. R. Beuchat, ed. ASM Press, Washington, DC.

Smyth, D. S., P. J. Hartigan, W. J. Meaney, J. R. Fitzgerald, C. F. Deobald, G. A. Bohach, and C. J. Smyth. 2005. Superantigen genes encoded by the egc cluster and SaPIbov are predominant among Staphylococcus aureus isolates from cows, goats, sheep, rabbits and poultry. J. Med. Microbiol. 54:401-411.

Smyth, R. W., G. Kahlmeter, L. B. Olsson, and B. Hoffman. 2001. Methods for identifying methicillin resistance in Staphylococcus aureus. J. Hosp. Infect. 48:103-107.

Tamura, K., J. Dudley, M. Nei, and S. Kumar. 2007. MEGA4: Molecular evolutionary genetics analysis (MEGA) software version 4.0. Mol. Biol. Evol. 24:1596-1599.

van Leeuwen, W. B., D. C. Melles, A. Alaidan, M. Al Ahdal, H. A. M. Boelens, S. V. Snijders, H. Wertheim, E. Van Duijkeren, J. K. Peeters, and D. S. Van. 2005. Host- and tissue-specific pathogenic traits of Staphylococcus aureus. J. Bacteriol. 187:4584-4591.

Virgin, J. E., T. M. Van Slyke, J. E. Lombard, and R. N. Zadoks. 2009. Methicillin-resistant Staphylococcus aureus detection in US bulk tank milk. J. Dairy Sci. 92:4988-4991. 